\title{
Lefort: 0 trabalho da obra de pensamento
}

Lefort: The Work of the Thought's Work

\author{
Marilena Chaui \\ Universidade de São Paulo | São Paulo | Brasil \\ Professora Emérita da Faculdade de Filosofia, Letras e Ciências Humanas
}

\section{RESUMO}

Um dos elementos fundamentais da leitura lefortiana de Maquiavel é o reconhecimento da distância que separa o maquiavelismo e a obra maquiaveliana. De fato, Lefort indaga de onde vem a imagem do maquiavelismo, que acompanha a leitura da obra maquiaveliana na fieira dos tempos. Para responder e desmantelar essa imagem, o autor interroga o que é o novo buscado por Maquiavel quando este, examinando as cidades italianas, particularmente a Florença do quattrocento e cinquecento, propõe as figuras do príncipe novo e da ordem nova. Essas figuras assinalam o lugar onde nasce a obra maquiaveliana como interrogação sobre a gênese da política a partir da interrogação sobre a experiência do presente político.

\section{PALAVRAS-CHAVE}

Maquiavel; Claude Lefort; Política; Experiência; Príncipe; Obra.

\begin{abstract}
One of the fundamental elements of Machiavelli's Lefortian reading is the recognition of the distance that separates Machiavellianism and Machiavellian work. In fact, Lefort asks where the image of Machiavellianism comes from, which accompanies the reading of the Machiavellian work through the vein of times. To answer and dismantle this image, the author questions what Machiavelli is looking for when he examines Italian cities, particularly Florence in the quattrocento and cinquecento, proposing the figures of the new prince and the new order. These figures point to the place where the Machiavellian work is born as a question about the genesis of politics from the interrogation of the experience of the political present.
\end{abstract}

\section{KEY WORDS}

Machiavelli; Claude Lefort; Politics; Experience; Prince; Work. 


\section{I}

Um percurso interessante para circunscrever o lugar de onde fala Lefort nos é dado por um dos elementos fundamentais de sua leitura de Maquiavel, qual seja, a distância entre o maquiavelismo e a obra maquiaveliana.

De fato, Lefort indaga de onde vem a imagem do maquiavelismo, que acompanha a leitura da obra maquiaveliana na fieira dos tempos. Para responder e desmantelar essa imagem, Lefort interroga o que é o novo buscado por Maquiavel quando este, examinando as cidades italianas, particularmente a Florença do quattrocento e cinquecento, propõe as figuras do príncipe novo e da ordem nova. Essas figuras assinalam o lugar onde nasce a obra maquiaveliana como interrogação sobre a gênese da política a partir da interrogação sobre a experiência do presente político.

Para a tradição, a política era obra da Natureza, como supunham os aristotélicos, ou da Razão, como supunham os platônicos, ou de Deus, como supunham os teólogos. Por seu turno, Natureza, Razão e Deus eram imagens inseparáveis da figura da sociedade como comunidade una e indivisa, do poder como unidade indissolúvel da lei e do saber, isto é, como legitimidade juridicamente fundada, permitindo distinguir os regimes políticos como legítimos ou ilegítimos. A ruptura maquiaveliana se desenha nas primeiras linhas de $O$ Principe, quando, abandonando a figura da legitimidade ou ilegitimidade do poder, isto é, a perspectiva ético-jurídica, e a distinção tradicional dos regimes políticos pelo número de governantes, Maquiavel simplesmente afirma que o império (em seu sentido originário de comando) pode ser uma república ou um principado e que este pode ser hereditário, por conquista ou novo. A ruptura prossegue à medida que Maquiavel nega que a política seja obra da Natureza, da Razão ou de Deus, afirmando que ela é a maneira como uma sociedade efetua sobre a divisão originária que a constitui ou a divisão entre dois humores: o desejo de dominação e opressão e o desejo puramente negativo de não ser dominado nem oprimido. Está desfeito o núcleo do imaginário político forjado pela tradição, isto é, a imagem da Boa Sociedade ou da comunidade una e indivisa. Se a política nasce para responder à questão da divisão originária do social é porque ela é o trabalho que a sociedade realiza sobre si mesma para transformar a violência ou a lógica da força em lógica do poder. E esse trabalho só é possível conferindo ao poder uma dimensão simbólica, à distância de sua figuração imaginária como poder dos grandes (que estariam destinados a ele por Natureza) e do bom governante (figurado pelo exercício da reta razão e das virtudes principescas). Com isso também está desfeito o fundamento que a tradição dera ao político sob a imagem do Bom Poder, desmantelamento atestado pela concepção maquiaveliana do par virtù-fortuna, isto é, a relação entre política e história, ou a verità effetuale delle cose, que ensina, de um lado, que a fortuna é o nome dado à adversidade, e, de 
outro, que a virtude principesca consiste em ajustar-se ao movimento da fortuna para dobrá-la e o único princípio do príncipe virtuoso é, exatamente, não atar-se a nenhum princípio, pois, se o fizer, será incapaz de operar com a contingência dos acontecimentos.

Compreendemos, então, que a imagem do maquiavelismo nasce quando o leitor de $O$ Príncipe se recusa a compreender a gênese da política e as formas do exercício efetivo do poder postas pela obra maquiaveliana ao desmantelar os referenciais postos pela tradição do pensamento político.

Maquiavel interroga a experiência do presente como enigma e indeterminação que pedem o trabalho do pensamento. Ora, isto descreve o trabalho da obra do próprio Lefort. Por um lado, basta lembrarmos a insistência com que se refere à ausência de um pensamento sobre a política que se debruce sobre a experiência presente para decifrá-la e compreendê-la; por outro, basta considerarmos as questôes que o preocuparam e para as quais trouxe o sopro benfazejo do novo: burocracia, ideologia, revolução, totalitarismo, democracia, a filosofia como aventura sem garantias e a ideia de obra de pensamento, para mencionarmos algumas das mais significativas.

\section{II}

No caso da burocracia, Lefort recusa tomá-la como um fato bruto e sobretudo como uma organização formal administrativa circunscrita à esfera do Estado, seja no sentido dado por Marx de irracionalidade e irresponsabilidade, seja no sentido dado por Weber, de racionalidade impessoal. Examinando a pluralidade de instituiçôes burocráticas, propõe tomar a burocracia como formação social historicamente determinada ou como uma mentalidade e um sistema de comportamento dotados de sentido por meio de suas articulações com as determinaçôes políticas, econômicas e culturais. Em suma, preocupa-se em acompanhar a gênese da burocracia como uma forma determinada da sociabilidade nas sociedades modernas e sua exasperação no totalitarismo, considerando-a a formação social fundada na crença da racionalidade em si do social, racionalidade encarnada na ideia de organização, concebida como sistema hierárquico de cargos e funçôes que opera sob o signo do segredo e da rotina e da identificação de cada um de seus membros com o cargo que ocupa e a função que executa.

No caso da ideologia, Lefort não só recusa que ela seja reflexo da estrutura econômica e mera inversão do real, como também recusa a ideologia do fim das ideologias. A ideologia não é um ideário ou um sistema coerente de ideias que inverte a realidade e que se desmantela com a chegada da verdade trazida pela ciência da história (como julgara Althusser, por exemplo), mas um imaginário social que assume a forma de um discurso sobre o social que pretende coincidir com 
o próprio social e tornar-se discurso do social. Esse discurso tem a peculiaridade de pretender afirmar a transparência do social e, simultaneamente, não conseguir realizar essa pretensão a não ser como discurso lacunar cujas lacunas não podem ser preenchidas sob pena de desfazer-se como discurso. A suposta transparência do social para si mesmo só se efetua graças a três dissimulações constitutivas do discurso ideológico: a dissimulação da divisão social sob a figura da comunidade una e indivisa, a dissimulação da diferença temporal sob a figura da diferença dos tempos, e a dissimulação da divisão entre o saber e o agir. Numa palavra, a dissimulação das contradiçôes. Se é esta a gênese das ideologias nas sociedades modernas, contudo é essencial não perder de vista o plural ideologias, pois é nele que podemos ler o novo. Com efeito, para propor a compreensão das ideologias como imaginário social, Lefort se detém nas diferenças entre a ideologia burguesa, a totalitária e a das sociedades democráticas contemporâneas, que designa com a expressão ideologia invisível — na ideologia burguesa, a transparência é dada pela exterioridade entre o discurso e o social sob as figuras da regra e da norma universais, que, proferidas pedagogicamente do alto, constituiriam a ordem das próprias coisas; na ideologia totalitária, a transparência é dada pela identidade entre o social e o seu aparecer por meio da identificação entre o Estado e a sociedade civil, isto é, por um discurso que veicula o princípio do poder como princípio de todas as atividades sociais, econômicas e culturais; na ideologia invisível, a transparência do social é produzida pelos meios de comunicação de massa que, sob a crença na eficácia da ciência e do discurso do especialista, que ofereceriam a racionalidade em si do social, visam à homogeneização do social sob a forma do espetáculo como forma da relação social, definida como um entre-nós, um grupo imaginário de inclusão social que dissimula a diferença e a distância entre o emissor e o receptor do discurso, isto é, a relação de dominação.

No que concerne ao totalitarismo, nos vários ensaios em que o discutiu, Lefort sempre indaga por que as esquerdas deixaram a cargo da direita a compreensão e a crítica desse fenômeno político. No caso das esquerdas, conclui ele, duas barreiras se ergueram para ocultar a questão: de um lado, o próprio pensamento de Marx que, detendo-se apenas na esfera econômica do social, não formulou um pensamento da política; de outro, a dissimulação do stalinismo sob a bandeira da defesa do "socialismo em um só país", fazendo com que as esquerdas temessem prejudicar a causa da revolução comunista com a crítica à União Soviética. Além dessas duas barreiras, ergueu-se também o peculiar obstáculo criado pela crítica de Trotsky, que alimentou o imaginário do totalitarismo como ditadura burocrática a ser vencida pela revolução permanente, ou a imagem de um Estado proletário desfigurado que ainda iria encontrar sua verdadeira figura. O totalitarismo, diz Lefort, não é um produto de uma etapa do modo de produção capitalista - um 
fenômeno na superfície da economia - e não é uma ditadura burocrática nem um despotismo à outrance, mas é uma mutação histórica da política ou uma nova figura do político. Sob essa perspectiva, é possível responder de uma outra maneira à pergunta por que as esquerdas não foram capazes de compreendê-lo e criticá-lo. Para isso, é preciso começar colocando lado a lado duas ficçōes sobre a sociedade, a ficção liberal e a ficção comunista. A ficção liberal afirma uma sociedade que se ordena espontaneamente sob a livre concorrência dos proprietários privados, cabendo ao Estado fazer respeitar as regras do jogo, protegendo a propriedade privada dos meios de produção. A ficção comunista afirma uma sociedade que se ordena espontaneamente pela organização da produção econômica sob a direção dos trabalhadores. A ficção liberal e a comunista possuem um traço comum: ambas desconhecem a sociedade politica, pois circunscrevem a realidade à esfera econômica e ficam cegas para o sistema político no qual a economia se inscreve. Como aparece essa cegueira? Responde Lefort: no fato de que liberais e comunistas concebem o Estado como simples órgão da sociedade, diferenciando-se dela para exercer funções de interesse geral e essa concepção leva os liberais a acreditar na imagem do Estado separado da sociedade e os comunistas, na imagem do Estado consubstancial à sociedade no qual estão figurados os interesses gerais. É essa visão orgânica ou organicista do poder que torna impossível compreender o fenômeno do totalitarismo.

I Gostaríamos de assinalar que essa crítica de Lefort ao organicismo ou instrumentalismo ilumina sua crítica a Arendt e sua distância com relação a Foucault, isto é, ambos, de maneiras distintas e referidos a sociedades distintas, pensam o poder de maneira orgânica ou organicista, ou seja, como órganon ou instrumento de ação - eis por que Arendt idealiza a pólis grega, na qual o poder não teria se separado da sociedade, e por que Foucault pensa numa microfísica do poder e num biopoder, isto é, formas de controle, disciplina, vigilância e normalização que informam e enformam o social, ou seja, órgãos ou instrumentos institucionais que capilarizam o poder no todo social. Com relação a Arendt, diremos que ela concebe a política como práxis pura, uma ação desligada de todo e qualquer labor e de todo e qualquer fazer, em suma, sem relação com a poiésis (basta lembrarmos as análises de Moses Finley sobre a democracia grega para percebermos a idealização arendtiana). Ao contrário, diremos que Foucault concebe a política como pura poiésis, como puro fazer sem ação, a melhor prova disto estando no conceito chave de seu pensamento, qual seja, a de dispositivo ou o poder concebido como conjunto de dispositivos, isto é, instrumentos. Numa palavra, Arendt, do lado liberal, e Foucault, do lado socialista e libertário, não alcançam a dimensão propriamente política do poder ou, como diz Lefort, a sociedade política. Escreve Lefort: "O fenômeno do poder está no centro da análise política, mas não porque há uma autonomia da relação de poder (esta reduzida a sua mais simples expressão de dominação de um homem ou de um grupo sobre uma coletividade não nos ensina nada); é porque a existência de um poder suscetível de obter a obediência e a fidelidade generalizadas implica um certo tipo de divisões e de articulaçóes sociais, ao mesmo tempo que um certo tipo de representaçóes, em parte explícitas e, em maior parte, implícitas, concernentes à legitimidade da ordem social. Não nos contentemos sequer em dizer que não há poder que não requeira procedimentos de legitimação pois seria forjar a ficção de um poder nu [...] Mas, antes de apreciá-lo, 
O totalitarismo é a fantasmagoria "de uma sociedade que se instituiria sem divisões, disporia do domínio de sua organização, se relacionaria consigo mesma em todas as suas partes, seria habitada pelo mesmo projeto de edificação do socialismo". ${ }^{2}$ Nele, o poder se afirma como poder social, isto é, ele figura a própria sociedade como potência agente e consciente. Em suma, não há distância ou separação entre sociedade civil e Estado e o poder se materializa num indivíduo capaz de concentrar nele próprio todas as forças sociais. Ao mesmo tempo, a sociedade deve aparecer sem divisões, de sorte que a empresa de produção, a administração, a escola, o hospital, a instituição judiciária, as artes, as ciências aparecem como organizações parciais subordinadas à grande organização socialista. Recusa-se a heterogeneidade social, a pluralidade de modos de vida, de comportamentos, de crenças e opinióes, costumes, gostos, ideias para oferecer a imagem de uma sociedade em concordância e consonância consigo mesma. "O processo de identificação entre o poder e a sociedade, o processo de homogeneização do espaço social, o processo de fechamento tanto da sociedade como do poder se encadeiam e se conectam para constituir o sistema totalitário"3. A isso é preciso acrescentar o conjunto de representações que constituem a ideologia totalitária: a imagem do Povo-uno, combinada com a do Poder-uno; a imagem do inimigo como outro que o povo ou como "inimigo do povo", alteridade interna à sociedade, figura da perversão, da doença e da dissidência; a metáfora do corpo (as células) ou a imagem da sociedade como uma vasta rede de organizações e micro-organizações que formam a sociedade totalitária, cujo agente privilegiado é o Partido, que produz uma rede interminável de coletivos aparentemente autônomos, mas nos quais se refaz a imagem da identidade social comum e de uma direção comum; e a imagem do fim da história. Lefort lembra a expressão cunhada por Trotsky que este, entretanto, não chegou a desenvolver numa análise do fenômeno totalitário e que é uma chave precisa para sua compreensão: "a Sociedade sou eu", distinta da expressão absolutista "o Estado sou eu". Em outras palavras, trata-se de um poder social investido num único indivíduo.

é necessário decifrar as condições que o tornaram possível, perguntar-se em cada caso dado que a mudança nos princípios de legitimidade, que remanejamento no sistema de crenças, no modo de apreensão da realidade permitiram que uma nova figura do poder se desenhasse. E dizemos "figura" para dar a entenderque é da essência do poder fazer-se ver e tornar visível um modelo de organização social”, em suma, compreender que se trata da sociedade política. (Lefort, Claude, "A lógica totalitária", A Invenção Democrática. Trad. de Isabel Loureiro. São Paulo: Brasiliense, 1983, pp. 78-79).

2 Lefort, Claude, "A lógica totalitária”, A Invenção Democrática. Trad. de Isabel Loureiro. São Paulo: Brasiliense, I983, p. 8I.

3 Ibid.. 
É exatamente essa investidura que marca a diferença do poder na sociedade totalitária e nas democráticas:

Nestas, ele [o poder] já se mostra social, no sentido de que a origem da soberania está colocada no povo; mas a manifestação dessa soberania está rigorosamente submetida a procedimentos fixados pelo direito. Logo, não há povo - na acepção política do termo - que seja definido por um direito, que escapa ao poder [...] A mesma razão faz com que o poder seja limitado de direito e não possa confundir-se com a potência dos que o exercem; e a mesma razão faz com que não haja povo fora da operação regulamentada de sufrágio e que não haja poder susceptível de encarná-lo. ${ }^{4}$

Todavia, essa diferenciação, em vez de ser apaziguante, pelo contrário, nos conduz a um dos aspectos mais dramáticos e gigantescos da análise lefortiana do totalitarismo. Com efeito, quando nos acercamos da questão que ocupa toda a obra de Lefort, qual seja, a gênese da democracia moderna, descobrimos ser nela que Lefort encontra inscrita a possibilidade da gênese do totalitarismo enquanto figura da política.

Para pensar a gênese das democracias modernas e a experiência política do presente é preciso afastar, de um lado, o marxismo, que reduz a política à condição de super-estrutura, e, de outro, as ciências sociais, particularmente a sociologia e a ciência política, pois estas buscam seu objeto de conhecimento a partir da construção ou delimitação do "fato político", considerado um fato particular ao lado de outros fatos sociais particulares (econômico, jurídico, científico, estético, ou simplesmente social, isto é, como modo de relação entre grupos e classes). Escreve Lefort:

Tal perspectiva pressupõe que sub-repticiamente fazemos referência a um espaço denominado sociedade. Pretende-se inventoriá-la ou reconstituí-la pondo termos, articulando-os, forjando sistemas particulares de relações, até mesmo combinando-os em um sistema global, como se a observação ou a construção não derivasse de uma experiência da vida social, ao mesmo tempo primordial e singularmente modelada por nossa inserção em um quadro histórico e politicamente determinado. Ora, observemos de imediato uma consequência dessa ficção: as sociedade democráticas modernas se caracterizam, entre outras, pela delimitação de uma esfera de instituições, de relações, de atividades que aparece como política, distinta das outras esferas que aparecem como econômica, jurídica, etc.

4 Lefort, Claude, "Staline et le stalinisme", L'invention démocratique, op. cit., p. I2O. 
Politólogos e sociólogos encontram nesse modo de aparecer do político a condição da definição de seu objeto e de seu percurso de conhecimento, sem interrogar a forma de sociedade na qual se apresenta e se legitima a clivagem entre diversos setores da realidade.

A atitude da sociologia e da ciência política nasce de uma vontade de objetivação e do esquecimento de que não existem elementos ou estruturas elementares, nem relações sociais, nem determinações econômicas e técnicas pré-existentes ao espaço social — não há dimensões do espaço social antes da formação social. Essa atitude as priva de pensar sobre uma experiência que se engendra e se ordena em virtude de uma concepção implícita das relações dos homens entre si e deles com o mundo. Essa atitude lhes interdita pensar

o que é pensado em toda sociedade e lhe dá o estatuto de sociedade humana: a diferença entre legitimidade e ilegimitidade, entre verdade e mentira, autenticidade e impostura, a busca da potência ou do interesse privado e a busca do bem comum. ${ }^{6}$

Eis por que Lefort distingue entre a politica — o conjunto de instituições que uma sociedade formula para o exercício do poder e para as quais se voltam a sociologia e a ciência política - e o político - aquilo que dá a uma sociedade seu estatuto de sociedade humana.

Entretanto, para interrogar a democracia moderna é preciso também afastar a concepção liberal, que a define como o regime da lei e da ordem para a garantia das liberdades civis. A democracia não é um regime político, é uma formação social. Donde a expressão introduzida por Lefort: sociedade democrática.

A sociedade democrática moderna nasce com a desincorporação do poder, isto é, da imagem do poder encarnado no corpo místico do rei como governante que detém a lei e o saber ${ }^{7}$, como atesta a expressão "o Estado sou eu", este "eu" não sendo a pessoa física do rei e sim sua figura mística ou seu corpo político, que, espelhado pelo social, estrutura a hierarquia e a ordem sociais. A diferenciação entre o poder, a lei e o saber desfaz a figura da sociedade hierárquica e ordenada

5 Lefort, Claude, "La question de la démocratie", Essais sur le politique. XIXe-XXe siècles. Paris: Seuil, 1996, p. I9.

6 Ibid.

7 Lefort trabalha a partir das análises da figura do poder incorporado desenvolvidas por E. Kantorowicz em Os dois corpos do rei (São Paulo: Companhia das Letras, 1998), com a distinção entre o corpo humano e mortal do rei e seu corpo político, imortal e místico, unidade indissolúvel do poder, do saber e da lei, constituído por sua sagração como rei pela graça de Deus que confere à sua pessoa a dupla figura de Cristo como homem mortal e deus imortal. 
como espelho do corpo uno do governante. Numa palavra, a democracia moderna nasce quando se apaga a imagem da transcendência do poder como garantidor do social que se acredita nascido da vontade e do saber do detentor do poder: a desaparição da transcendência do fundamento - nem a Natureza, nem a Razão nem Deus, como já mostrara Maquiavel — leva à figura da imanência, isto é, à ideia do poder popular ou do poder social como origem do poder político. Todavia, isso não basta para alcançar a gênese da democracia moderna tal como Lefort a concebe.

Com efeito, a desincorporação do poder significa que não há uma ordem e uma determinação pré-existentes ao social que lhe dariam forma e sentido. Em outras palavras, a sociedade democrática nasce e vive na indeterminação, pois ela não é senão o trabalho para vencer sua falta de determinação. Essa indeterminação aparece, em primeiro lugar, porque a democracia é a única formação política que considera o conflito legítimo e a única que não o oculta, mas se abre ao trabalho temporal dos conflitos; em segundo lugar, porque a sociedade democrática faz a descoberta da ideia e da prática dos direitos e age como criação ininterrupta de novos direitos, ou seja, trabalha na criação do novo e na diferença temporal que ele acarreta; mas, em terceiro lugar e sobretudo, porque a ideia de poder popular não dá conta do verdadeiro significado do poder democrático, qual seja, que ele não se identifica com ninguém, não pertence a ninguém e ninguém pode identificar-se com ele e ele só age porque é um lugar vazio que não pode ser ocupado sob pena de destruir-se como poder democrático.

O lugar do poder encontra-se, assim, tacitamente reconhecido como um lugar vazio, por definição inocupável, um lugar simbólico e não um lugar real. ${ }^{8}$

A identificação da democracia com o poder popular torna ilegível a divisão social entre dominantes e dominados, porém isto não é suficiente para apreender a novidade democrática, pois corremos risco de forjar uma figura positiva e completamente determinada - o Povo - como um fundamento que apaga a divisão social, pois totaliza num único sujeito fictício dominantes e dominados. Pelo contrário, conceber a democracia como o lugar vazio do poder significa manter visível a divisão social e tornar inteligível tanto a legitimidade dos conflitos como luta por esse lugar, quanto a criação de direitos engendrados por essa luta. A democracia revela a dimensão simbólica do poder e a impossibilidade da transparência do social a si mesmo. Conflito, criação do novo, lugar vazio: a democracia torna

8 Lefort, Claude "Staline et le stalinisme", L'invention démocratique, p. I2I. 
indeterminados os fundamentos últimos do saber, da lei e do poder em todos os registros da vida social, sendo por isso mesmo a formação política aberta à temporalidade, carregando consigo uma indeterminação que lhe é constitutiva, pondo em xeque tanto a imagem do Bom Poder como a da sociedade como comunidade orgânica ou a Boa Sociedade, uma sociedade concorde consigo mesma e capaz de dominar sua história.

Ora é exatamente a indeterminação que torna possível a passagem da democracia ao totalitarismo. Quando a insegurança dos indivíduos cresce em decorrência de uma crise econômica ou das destruiçōes de uma guerra, quando o conflito entre as classes e os grupos não consegue resolver-se na esfera política, quando o poder aparece como poder privado a serviço dos interesses e ambições de alguns particulares, a sociedade se mostra despedaçada, suscitando o fantasma do Povo-Uno, a busca de uma identidade substancial, de um corpo social soldado à sua cabeça, de um poder encarnado, de um Estado livrado da divisão.?

A democracia, experiência da indeterminação última dos fundamentos da ordem social, destrói a ficção da Boa Sociedade una e indivisa; o totalitarismo, nascido da indeterminação democrática, repõe essa figura, pretendendo fazer coincidir o real e o racional e, finalmente, fechar a história.

\section{III}

Essas brevíssimas considerações tornam inteligível o aparecimento da expressão obra de pensamento, com que Lefort explicita seu próprio percurso interrogativo e o dos pensadores a que dedicou muitos de seus ensaios e livros. Ao apresentá-la, ele o faz como no tratamento das demais questōes que mencionamos até aqui, isto é, tomando distância daquilo que tornaria impossível concebê-la. De um lado, recusa explicitamente a afirmação de Foucault de que a noção de obra é uma ilusão, pois, segundo este, não haveria como determinar o que a constitui e o que lhe é exterior (cartas, bilhetes, diários íntimos, rascunhos abandonados, textos assumidos?) - uma obra, diz Foucault, é apenas um conjunto de textos aos quais se atribui um nome próprio. De outro, Lefort recusa explicitamente a posição exatamente inversa, qual seja, a de Bréhier e Guéroult, que concebem uma obra como uma representação completamente determinada, uma estrutura, um sistema que tanto o autor quanto o intérprete dominam completamente.

A obra de pensamento, escreve Lefort, tem uma existência enigmática. Interrogando o lugar de origem de sua própria expressão, realiza um estranho movimento que a obriga a se afastar dessa origem que ela procura determinar.

9 Cf. Lefort, Claude, "A imagem do corpo e o totalitarismo", A Invenção Democrática, p. II7 e ss. 
Nascida do desamparo da experiência imediata, suscitada pelo não-saber e pelo não-agir do presente, a obra de pensamento renuncia ao imediato e desenterra uma espécie de segredo da experiência, desde que se possa ler ali o que permanecia oculto. $\mathrm{O}$ paradoxo está em que a obra precisa renunciar a isto que a faz nascer (a experiência imediata, o presente como não-saber e não-agir) para alcançar o sentido de seu próprio nascimento. Numa palavra: a obra põe a diferença entre experiência e reflexão.

A esse paradoxo - a obra como ocultamento de sua origem - vem acrescentar-se um outro: a reflexão inaugurada pela obra é abertura de um campo de racionalidade novo que, no entanto, logo submerge sob os discursos que ela própria passa a suscitar. Ao nascer, a obra institui a diferença originária entre experiência e reflexão, e, ao falar, a obra institui o espaço simbólico da palavra como diferença originária entre escrita e leitura ou como divisão originária entre escritor e leitor. Contudo, assim como a reflexão visa conjurar a indeterminação da experiência, criando um saber sobre ela, assim também a leitura visa conjurar a separação entre o escritor e o leitor, separação sem a qual não há discurso. Dessa maneira, a obra de pensamento tende a promover discursos que, ignorantes de sua própria origem no interior da divisão da palavra, buscam instalar-se fora desse campo que os torna possíveis, de tal maneira que a obra engendra a figura imaginária da exterioridade do leitor diante do texto que ele lê.

Nem por isso, entretanto, Lefort apresenta como corretivo do desejo de exterioridade a ilusão da coincidência entre leitor e escritor, pois, novamente, o discurso se perderia como discurso, visto que nele a diferença entre escrita e leitura é o que o constitui como discurso. O desejo de coincidência ou de perfeita interioridade significa que o leitor toma o texto como uma mensagem da qual se coloca como mediador, encarregando-se de transmitir ao presente uma verdade que acenava do fundo do passado, à espera do momento oportuno para sua deflagração. Nesse desejo de interioridade apaga-se uma outra diferença fundamental, qual seja, a diferença temporal. Esta não é a diferença empírica dos tempos (presente, passado, futuro) e sim a diferença entre a experiência que suscita a escrita e a experiência que suscita a leitura.

Escondida a diferença temporal entre a escrita e a leitura e escondida a divisão originária da palavra (escondido, portanto, o campo simbólico), a obra tende a ocultar-se num campo empírico imaginário em que se vê convertida ou em "coisa" (como parece supor Foucault) ou em "ideia" (como pretendem Bréhier e Guéroult) e, com isso, é ela que, agora, passa a ocupar o polo da exterioridade, que é cultivada pelo leitor "objetivo" e exorcizada pelo leitor "concernido". Do campo simbólico da diferença, a obra desliza para o campo empírico/imaginário da dualidade (dos tempos; da escrita e da leitura) e se perde como palavra que fala através do escritor e do leitor. 
Tomemos a maneira como Lefort lê uma obra de pensamento. Aparentemente, parece iniciar seu livro sobre Maquiavel com uma questão clássica nas introduções dos livros de interpretação: por que uma mesma obra suscita discursos múltiplos, díspares e mesmo contraditórios?

Essa questão, diz Lefort, costuma encontrar três tipos de resposta.

$\mathrm{Na}$ primeira, a multiplicidade e divergência das interpretações decorreria das condiçōes históricas, sociais e políticas dos diferentes leitores; a figura "histórica" do leitor seria, assim, a chave explicativa.

$\mathrm{Na}$ segunda, afirma-se que é preciso distinguir entre dois tipos possíveis de leitura, um dos quais, se aceito, afasta necessariamente o outro. Haveria uma leitura na qual o leitor, partindo de suas próprias condições históricas e posiçôes teóricas, procuraria em um certo autor a confirmação ou a recusa das teses do próprio leitor. Esse subjetivismo seria a causa da multiplicidade e das divergências das interpretaçóes. Haveria, porém, um outro tipo de leitura, a leitura objetiva, que pode dar um fim à multiplicidade e às divergências: abandonando as condiçôes históricas em que a obra foi produzida e aquelas nas quais a interpretação está sendo realizada, pois tanto as primeiras como as segundas são irrelevantes para a obra, o leitor se erige como observador neutro de um discurso acabado cuja coerência formal é a chave para sua compreensão, Por esse motivo, cabe ao leitor deter-se exclusivamente no que foi explicitamente escrito pelo autor e recusar o que foi apenas "sugerido" por ele. Esse segundo tipo de leitura tem a peculiaridade de poder afirmar que a multiplicidade das interpretações é eliminável de direito, desde que seja eliminada sua causa, qual seja, a interpretação. O leitor comenta, não interpreta.

Finalmente, o terceiro tipo de resposta à questão tradicional é denominado por Lefort "leitura ficcionista", para opô-la às duas primeiras, que se julgam realistas e objetivas. Agora, a multiplicidade, os antagonismos e as contradiçôes das leituras se convertem em signo indicativo da natureza da obra de pensamento como idêntica à natureza da obra de arte entendida como mera ficção: ambas são obras fictícias. Se assim não fosse, uma obra de pensamento deveria admitir uma única leitura, como convém a um objeto do conhecimento. $\mathrm{Na}$ verdade, esse terceiro tipo de resposta é esclarecedor dos dois primeiros, aos quais pareceria opor-se, porque oferece um elemento novo, qual seja, a distinção imediata e simplista entre o real e o imaginário como distinção entre o dado (empírico ou ideal) e a fantasia arbitrária. Dessa maneira, obras como O Príncipe e O Dezoito Brumário levariam a uma exacerbação da leitura ficcionista, que contrapõe pessoas e situações "reais" às personagens e situaçôes "inventadas" pelo discurso. Mais realista e mais objetivista do que os dois tipos anteriores, esse terceiro tipo de leitura deixa escapar a dimensão essencial da obra de pensamento, isto é, sua dimensão simbólica. 
Assim, quando nos aproximamos do texto de Lefort, podemos observar que não só sua questão não é a questão tradicional sobre a multiplicidade e as divergências das interpretaçóes como também questiona essa questão, expondo seus pressupostos. Com efeito, a questão de Lefort não é: por que uma mesma obra de pensamento suscita discursos múltiplos, antagônicos e contraditórios? Sua questão é: por que uma obra de pensamento suscita discursos? Lefort interroga a própria emergência da leitura e de um novo discurso, nascido do ato de ler. O enigma da obra de pensamento não está em suscitar múltiplos discursos díspares e sim no simples fato de suscitar discursos, possuir uma posteridade, ter uma data e transcendê-la. É esse enigma que a questão tradicional escamoteia.

A questão tradicional está polarizada entre dois termos: a "mesma obra" e as "muitas leituras". A questão de Lefort se debruça sobre o "mesma". Entre o "mesma" e o "muitas", postos tradicionalmente como exteriores um ao outro, vem intercalar-se algo que esclarece e anula essa oposição: a noção de trabalho da obra como constituinte de seu ser como discurso, isto é, como escrita $\boldsymbol{e}$ leitura.

Qual o pressuposto da questão tradicional? Que deve haver uma única leitura verdadeira de uma obra, pois a verdade exige a univocidade e esta só é possível se a leitura estiver debruçada sobre um objeto, isto é, algo que é em si unívoco e idêntico. A pretensão de realizar uma leitura objetiva que ofereça de uma vez por todas a identidade da obra pressupóe que esta seja uma realidade completamente determinada, quer seja tomada como um "fato discursivo" quer como uma "ideia". Subjaz, portanto, a esse tipo de leitura a apreensão da obra de pensamento como uma representação, isto é, como objeto de_conhecimento, portanto, dotada de determinação completa. Dessa maneira, o discurso da obra aparece, de fato, como auto-suficiente, completo, acabado e, de direito, como dominável, primeiro, pelo entendimento do escritor e, a seguir, pelo do leitor. Supor que ambos não a dominam, que a obra é essencialmente indeterminada e aberta para ambos é o que esse tipo de interpretação recusa explicitamente.

Por isso, nas três respostas e nos três tipos de leitura delas nascidos encontra-se sempre presente, diz Lefort, o mesmo desejo de determinação, a mesma tentativa de submeter a obra a uma representação, isto é, à condição de objeto, o mesmo esforço para desfazer definitivamente aquilo que há de perturbador nela: a abertura de perspectivas intermináveis. Nessas leituras, a trama do próprio discurso é negligenciada, pois ela só pode surgir quando se tornam sensíveis as articulaçôes que comandam a forma tomada pelo discurso do escritor (muito precisamente, a seleção de algumas de suas proposições num arranjo novo, segundo uma nova ordem significativa), quando a determinação de um campo de realidade, em cujo interior a obra considerada em seu conjunto, ou na série de suas ideias, apareça não como um objeto e sim como um acontecimento, e quando se torna 
manifesta a afirmação de um saber sobre a essência daquilo que é proferido pelo discurso do escritor. Enquanto fundadora de um saber despojado de garantias transcendentes, a obra de pensamento é um fazer-se discurso, habita em suas palavras e é habitada por elas, e estas são sempre essencialmente dirigidas a um outro, o destinatário desconhecido ao qual o autor se dirige. Porque a obra é um fazer-se, $a$ indeterminação mora em seu coração e essa indeterminação é a abertura que a destina a ter uma posteridade. Abrindo um campo de pensamento que o escritor desejaria fechar e não pode fechar, a obra de pensamento suscita de seu próprio interior o discurso de um outro, que a faz falar novamente: a obra de pensamento é aquela que, ao pensar, dá a pensar.

A obra de pensamento institui uma experiência singular ao transfigurar a experiência histórica em expressão teórica. Que experiência singular é essa? O trabalho da obra como reflexão cuja exposição é interminável. A obra institui uma posteridade porque há um excesso do pensamento frente ao que está explicitamente pensado, excesso que suscita novos pensamentos, novos discursos, nova expressão. Isso não significa, porém, introduzir a distinção entre o espírito e a letra, pois, neste caso, como nos anteriores, o excesso do pensamento do escritor tornar-se-ia, de direito, dominável pelo leitor, quando, efetivamente, aquilo que, uma vez posto pelo discurso do escritor, não pode mais deixar de ser retomado pelos discursos subsequentes dos leitores.

Essa indeterminação constitutiva da obra de pensamento, que a faz existir no texto de seu autor e nos textos de seus leitores, é o que a leitura objetivista e a ficcionista pretendem evitar. A exigência de um racional positivo completamente determinado, por parte da primeira (a obra como representação ou como objeto), ou a exigência de um irracional positivo, pela segunda (a obra como ficção) são armaduras vestidas pelo sujeito para assegurar sua própria identidade e não se deixar arrastar pela historicidade do pensamento, historicidade que ele encara como dispersão e dissolução de si próprio.

Escreve Lefort:

O enigma é que a obra está inteira em seu texto e, ao mesmo tempo, fora de seu texto, no contexto crítico, que não pode ser ignorado por aquele que quer conhecê-la. Mas dizer "ao mesmo tempo" já se presta ao equívoco. O enigma está em que a obra se ofereça inteira em seu texto e que, no entanto, ela seja o que ela é apenas pela relação que se estabelece entre esse texto e seus leitores. ${ }^{\text {IO }}$

io Lefort, Claude, Le travail de l'ouvre. Machiavel. Paris: Gallimard, 1972, p. 44. 
A obra de pensamento está presente em seu texto e em suas leituras, ela é essa relação entre escrita e leitura.

A consequência é clara: conhecer uma obra de pensamento exige não a eliminação e sim a passagem pelas leituras que suscitou porque são constitutivas dela. Isto só é possível se deixarmos de tomá-la como objeto para vê-la como trabalho e, portanto, indissociável da experiência histórica que a suscitou ou de seu presente histórico e das leituras que ela suscitou e suscita. Isto não significa que todas as leituras sejam igualmente válidas, pois é preciso distinguir entre aquelas que produzem uma imagem da obra e aquelas que se debruçam sobre seu sentido. Sem a indeterminação, sem o excesso do pensamento sobre o pensado, a obra poderia ser reduzida a uma representação completamente determinada que liberaria o intérprete da árdua tarefa de articulá-la à história que a viu nascer e à de suas leituras.

É preciso ver o discurso carregando seu presente, transfigurando-o pela reflexão e transcendendo-o num espaço de racionalidade que permite, daí por diante, pensar uma certa dimensão do ser. A indeterminação essencial da obra, a imanência dos novos discursos a ela, a transcendência respectiva dela e deles frente aos seus presentes, revelam que escrever e interpretar são o mesmo - o escritor interpreta seu presente —, assim como ler e interpretar são o mesmo - o leitor interpreta a obra e, por meio dela, seu próprio presente, pois escrever, ler e interpretar são dimensões do pensamento como interrogação. A obra interroga seu presente, seus leitores a interrogam e interrogam seus próprios presentes. Interrogar é descobrir que "a obra conserva a virtude de fazer falar". Não é extrair da obra uma resposta para submetê-la ao nosso julgamento. É perceber o pensador como aquele que, de seu lugar próprio, interrogava a experiência para abalar os fundamentos do saber estabelecido, indo mais longe do que ele próprio e seus leitores seriam capazes de conceber.

Por que trabalho da obra? Em primeiro lugar, porque a obra é uma ação, um fazer-se, um acontecer. Em segundo, porque o trabalho (como a linguagem e a história) é relação com o ausente, um fazer vir ao mundo o que não existia, um possível instituído pela própria ação e não aquilo que a condicionaria (ela não atualiza um possível latente e sim torna possível algo que é posto por ela mesma). Em terceiro lugar, porque (nós o sabemos desde Hegel e Marx) o trabalho é negação da negação: a reflexão do escritor é negação do não-saber e do não-agir que constituem a experiência imediata de seu presente. A noção de trabalho da obra é a interrogação sobre a perigosa articulação entre saber e não-saber, que impossibilita reduzir a obra à positividade do fato ou da ideia (a racionalidade abstrata do saber objetivo) assim como à negatividade vazia de um irracional também positivo (a irracionalidade abstrata da falta de saber), pois tanto uma como outra fazem a obra pairar fora e acima da história: não tem história, não vive na história e não abre 
uma história, não se articula com a temporalidade. Trabalho da obra significa: a obra é criação. Eis por que Lefort retoma muitas vezes uma nota de trabalho de Merleau-Ponty em $O$ visivel e o invisivel em que essa ideia se explicita: "O ser é o que exige de nós criação para que dele tenhamos experiência". "I

Imersa numa história, a obra inaugura uma nova história, abre um campo de pensamento inédito graças às criticas das representaçôes instituídas, que obscurecem o presente e o porvir. Mas esse ato inaugural tem como solo um estado radical de não-saber. É como ausência de saber e de ação que o presente suscita a obra, cujo trabalho institui saber e ação. $\mathrm{O}$ não-saber não é ignorância, entendida como privação da verdade, mas é uma forma de "saber" cuja eficácia está justamente em ocultar o sentido do presente: chama-se ideologia.

A articulação entre saber e não-saber permite um esclarecimento maior do que pretende Lefort com a noção de trabalho da obra. Se, por um lado, ela já permite entrever a diferença entre o discurso crítico e o ideológico, por outro, já prepara o vínculo indissolúvel entre o escritor e o intérprete, pois o escritor também é um intérprete. Com efeito, afirmar a obra como trabalho significa que há uma matéria a ser transformada pela reflexão. Essa matéria é a experiência imediata e o trabalho consiste em desfazer a suposta positividade dessa matéria, descortinando as questôes que ela suscita e é incapaz de responder. O trabalho da obra começa quando revela o sono em que está mergulhada a experiência imediata, quando a desmente e a desmistifica, obrigando-a a pensar-se e, ao fazê-lo, conduzi-la a reconhecer-se como necessária $\boldsymbol{e}$ ilusória. Interpretar o presente é interrogá-lo para desfazer sua aparência, isto é, sua positividade e, com ela, a positividade atribuída tanto à imagem fixa do passado quanto a um cálculo apaziguador do futuro. Assim, a articulação entre saber e não-saber, que inaugura a obra como trabalho da reflexão, inaugura também a possibilidade de interrogar um outro trabalho, nascido do primeiro, qual seja, o da transformação do presente. Trabalho da obra: maneira de alcançar a obra em seu ponto mais obscuro nas articulações entre teoria e prática, nas dobras da historicidade.

\section{IV}

Gostaríamos de concluir fazendo uma breve alusão ao ensaio de Lefort intitulado, curiosamente, como uma pergunta: "Filósofo?".

Esse ensaio tem um tom e um percurso que nos fazem pensar em Montaigne e foi suscitado por uma pergunta feita ao autor: "Como você se tornou filósofo?". O tom lembra Montaigne porque nele reencontramos a mesma maneira de acercar-se da filosofia: a indagação sobre o pensar e o dizer, a narração de si pela

i I Merleau-Ponty, Maurice, Le visible et l'invisible, Paris: Gallimard, I964, p. 248. 
referência ao que recebeu de outros, a ironia e irreverência consigo mesmo e com a situação presente da filosofia, e, sobretudo, a indeterminação de si e da obra, descritas como experiência e aventura sem garantia e sem término. Impossível não lembrar como tão belamente escreveu Merleau-Ponty sobre a obra de Montaigne, no ensaio "Leitura de Montaigne", publicado em Signes: a caçada sem a caça.

Lefort afirma que embora a pergunta lhe tenha sido feita muitas vezes e que ela, de certo modo, se justifica, pois ele se recusa a ser nomeado como sociólogo, politólogo ou historiador, todavia, desta feita sentiu-se embaraçado para respondêla. Por um lado, porque haveria o risco de admitir um rótulo, por outro, porque não poderia aceitar aquilo em que a filosofia se tornou, isto é, uma disciplina particular com jurisdiçãao sobre as demais disciplinas, ou sua pretensão de ser a ciência do universal, mas também, por outro lado, não poderia aceitar o que se passa na França com a afirmação do fim da filosofia e uma ruidosa atitude iconoclasta. Porém, sobretudo, o que o embaraçava é que dizer-se filósofo talvez significasse ver-se acima de si mesmo. Decidiu, então, dizer-se professor porque, em primeiro lugar, ele de fato o é, em segundo, porque se trata de uma profissão e pode-se livremente mudar de profissão, mas em terceiro lugar, porque com isso talvez pudesse colocar-se abaixo de si mesmo. No entanto, pondera ele, não seria isso elevar a figura do filósofo e rebaixar a do professor? E não haveria aí o secreto desejo de rebaixar-se para poder elevar-se? Porém, chegado a esse ponto, Lefort indaga o que o teria levado à distinção entre acima e abaixo de si e responde que isso lhe veio da lembrança da obra de Kantorowicz sobre os dois corpos do rei e a designação do rei como maior e menor do que a lei. Mas por que se lembrara disso? Porque isso o remetia a uma leitura muito mais recente de uma outra obra, a de Quinet, sobre o fim da teologia política com a Revolução Francesa. Ora, Quinet repõe a questão da gênese da democracia moderna e o despertou para outros escritores que se interessaram pela desincorporação do poder, o que o levou a Michelet e Tocqueville. Mas a discussão da democracia moderna, ao colocar em cena o desejo de liberdade, o conduz à menção daquele que antecipou o significado da incorporação totalitária do poder: La Boétie. Este último e Quinet surgiram, juntamente com Sócrates, como figuras exemplares daquilo que Michelet chamou de "heroísmo do espírito", inspirando-se na expressão cunhada por Vico, "mente heroica", que o pensador napolitano empregara "para celebrar o risco de uma busca sem modelos, liberta da autoridade do saber estabelecido, muito apropriada para reivindicar o desejo desmedido de pensar para além da separação das disciplinas do conhecimento, em busca da verdade". ${ }^{\text {I2 }}$

I2 Lefort, Claude, "Philosophe?", Écrire à l'épreuve du politique. Paris: Calman-Lévy, I992, p. 339. 
Mente heroica e heroísmo do espírito: estas expressões designam para Lefort aqueles que tentam a tarefa impossível de desvelar o que é - o ser da sociedade, o ser da política, o ser da história, o ser do homem - e "criar, fazer surgir, pelo exercício de um direito vertiginoso do pensamento, da palavra, a obra em que advém o sentido". O heroísmo do espírito é o exercício pleno da liberdade como criação da obra de pensamento. Esse heroísmo faz ver "a experiência da contradição interna entre caída e recaída do desejo sob a atração da figura do Um e a conquista ou reconquista do desejo, por meio da liberdade desmedida, do pensamento desmedido, do exercício incognoscível da obra, essa experiência nos afasta de toda garantia de uma natureza humana" ${ }^{13}$

Não se trata, escreve Lefort, de propalar aos quatro ventos, como gostam alguns, que "o homem não existe" (ou que ele é uma invenção recente que será apagada como a figura na areia é apagada pelas ondas do mar) e sim, pelo contrário, que a ausência de uma natureza humana

Obriga a decifrar os sinais do que é, do que advém, apenas quando se assume o risco interminável do pensamento, da palavra ou da ação. Tendo consciência desse risco, senti-me fundamentado para me indagar se era legítimo referenciá-lo à definição da filosofia. ${ }^{14}$

Em suma, o pensamento, rumando vertiginosamente para a questão do Ser, isto é, para a ontologia, reconduz, ao fim e ao cabo, de volta à pergunta: "filósofo?". Mas Lefort a retoma por meio de um desvio aparente: em lugar do filósofo, faz entrar em cena a figura do escritor enquanto pensador.

Qual a questão originária que move o escritor, isto é, o pensador? A questão: o que é pensar? Não há questão mais originária do que esta. Mas como nomeá-la? $\mathrm{E}$, devendo ser nomeada, não seria na vida, no modo pelo qual o pensamento se engendra, que a questão encontra sua maior força?. Ora, visto que essa questão move todo pensador e todo escritor, como distinguir entre filosofia e não-filosofia?

Por isso, prossegue Lefort,

Parecia-me insuficiente responder que pode haver mais filosofia num livro de história, num trabalho de política, num romance ou num poema do que num tratado que leva esse nome. A resposta põe na sombra o que the cabe iluminar: o que se deve entender por filosofia? Quando se acreditava que se podia definir a filosofia pela maneira em que se distinguia da teologia no tratamento das questôes últimas, talvez então existisse um

I3 Ibid., p. 34I.

I4 Ibid., pp. 34I-342. 
critério, a fé [...]. Mas o nexo entre filosofia e teologia desfez-se, a tal ponto que cabe duvidar se a filosofia pode se deixar conceber como uma apropriação das questôes últimas, sobre as quais a teologia estendia sua jurisdição. A relação que se estabeleceu entre filosofia e ciência também não é de uma natureza que possa nos esclarecer. Dizer que a filosofia busca as condiçóes de possibilidade de novos percursos para as ciências seria reduzi-la aos limites da epistemologia. Dizer que busca formular questóes que se engendram nos percursos das ciências em devir não significa necessariamente que essas questões sejam últimas, que tenham um privilégio, que sejam mais pertinentes que as questôes que se engendram nas mutações que afetam a arte ou a literatura, ou a concepção da história ou a sensibilidade à história, ou a reflexão política, ou, de maneira geral, a relação dos homens com a política. Convir-se-á, de resto, que o esfacelamento da filosofia em filosofia da ciência, filosofia política, filosofia da arte... significa apenas sancionar o fracasso de se pensar a filosofia como tal. ${ }^{15}$

Assim como não é possível pensar a filosofia como uma disciplina particular, mesmo que se imagine que ela "supervisione" soberanamente as demais disciplinas ou a não-filosofia, assim também não se consegue pensá-la quando ela própria é esfacelada numa miríade de disciplinas cada qual com seu objeto próprio. $\mathrm{O}$ que se evidencia, portanto, é que a questão sobre a filosofia parece não encontrar resposta possível quando se descobre que nenhum objeto pode servir-lhe de referência. Essa indagação não é vã por não sabermos respondê-la e nos sentirmos desarmados, aliás, é o contrário que ocorre:

Essa interrogação se torna ainda mais insistente porque não diz respeito apenas à filosofia e chegou mesmo a ser reconhecida mais cedo em outros campos, principalmente na literatura e na arte — na pintura, na música. Se significa uma banalidade dizer que o pintor está, há muito tempo, e cada vez mais, confrontado à questão "o que é pintar?", é porque a ideia de uma essência da pintura, e o que a acompanha, uma essência da visão, furta-se a ele. Do mesmo modo, o escritor cede à vertigem da questão "o que é escrever?". A essência da literatura, e o que a acompanha, a essência da linguagem, furta-se a ele; enquanto se dissipa a certeza do que é o romance ou a poesia. ${ }^{16}$

Ora, a discussão sobre a diferença e a relação entre filosofia e não-filosofia foi,

Is Ibid., p. 346.

I6 Ibid. 
como sabemos, uma questão incessantemente posta e reposta por Merleau-Ponty, nome pelo qual estávamos à espera nesse curioso percurso textual que não se insere na linhagem do "elogio à filosofia". Merleau-Ponty, lembra Lefort, dirigiu-se às ciências, às artes, à política para decifrar o que não era nenhuma delas e que possui o enigmático nome de "filosofia". Descobriu que a essência das ciências, da literatura e da pintura se furtam ao cientista, ao romancista e poeta, ao pintor e que, como eles, também a essência da filosofia parece furtar-se ao filósofo e isso é mais grave, desde que se considere que a filosofia busca o ser daquilo que é.

$\mathrm{Na}$ trilha dessas interrogações [de Merleau-Ponty sobre a pintura e a literatura], eu havia por minha vez indagado se o filósofo não havia sido rondado, por um período ainda mais longo, pelo fantasma de um pensamento puro. E, ao convir, de acordo com a mesma inspiração, que o filósofo, em sua prática, sempre se consagrou a um trabalho de expressão, à produção de uma obra, durante a qual o pensamento se busca, por meio da escrita, ao mesmo tempo em que se desvela e se inventa, de tal sorte que jamais haveria transparência do pensamento a si mesmo, de tal sorte que essa noção não daria conta de seu percurso, eu concluía que essa busca, que a questão "o que é pensar?", ligada à questão da escrita, tornava-se cada vez mais, em nossos tempos, o que é próprio da filosofia. ${ }^{17}$

Assim, o que parecia ser um desvio diante da pergunta "filósofo?", isto é, o recurso à figura do escritor, se mostra constitutivo daquilo mesmo que, afinal, poderíamos chamar de filosofia, pois o filósofo se vê induzido a acolher, em vez de denegá-la, sua vocação de escritor, se vê induzido a reconhecer o que une filosofia e literatura. Ora, o que significa precisamente assumir essa ligação entre filosofia e literatura? Significa que,

Se a questão que o singulariza como filósofo é precisamente "o que é pensar?", esta não poderia se circunscrever, definir-se no sentido tradicional, como uma questão de conhecimento, como uma questão que põe um sujeito diante de seu objeto, como uma questão que convidaria a remontar a uma origem, a desenvolver e controlar as articulaçôes de um campo de consciência. ${ }^{18}$

A filosofia não se circunscreve ao campo do conhecimento como relação

I7 Ibid., p. 347 .

I8 Ibid., p. 348 . 
entre sujeito e objeto — isto é, como campo das representações — nem como determinação de uma origem completamente determinada que as operações do sujeito dominariam e controlariam. A relação entre filosofia e literatura ou o filósofo como escritor assinala que a questão "o que é pensar?" mergulha no contrário da representação completamente determinada como figura do saber, isto é, mergulha na indeterminação e é esta que dá origem à obra de pensamento e ao seu trabalho:

Trata-se de uma questão ilocalizável e indeterminável que acompanha toda experiência do mundo - surge de relações, mais sensíveis e mais gerais, inscritas em órgãos de nosso corpo, abrindo-o aos outros e às coisas ao mesmo tempo em que se imprimem nele, ou surge de relaçóes montadas por nós em virtude de nossa implicação numa cultura e, para além, numa história da humanidade. Nesse sentido, o que nomeamos como exigência filosófica nasceria, renasceria de toda parte, e seria regida, para o escritor-filósofo, pelo apelo da obra, na qual a questão permanece em busca de si mesma, reitera-se valendo-se de todos os lugares a que seu desejo singular a conduziu. [...] E, se para nos referenciar ao que nos põe a pensar, a falar, é preciso que deixemos nos demover pelo pensamento, pela fala, se o mesmo movimento nos desenraíza e nos enraíza, aquele que conhece a atração pela filosofia não deveria reivindicar essa errância, acolher deliberadamente essa vida nômade, envolver-se nesse turbilhão que, para cada um de nós, sem que saibamos, já institui e turva as fronteiras do aqui e do alhures, do dentro e do fora? ${ }^{\text {19 }}$

Filósofo? Sim, quando se lança sem temor no heroísmo do pensamento.

I9 Ibid. 